\title{
ATP2B3 Gene
}

National Cancer Institute

\section{Source}

National Cancer Institute. ATP2B3 Gene. NCI Thesaurus. Code C113765.

This gene plays a role in ATP-dependent calcium transport. 